\title{
Arte e mídia: a gestão da comunicação no Arte na Escola on-line
}

Monica Kondziolková

Especialista em Gestão da Comunicação pela Escola de Comunicações e Artes da USP.

E-mail: monica@artenaescola.org.br

O papel da comunicação em um site on-line de arte, fundamentado no conceito de consumo midiático, foi o tema do projeto de pesquisa desenvolvido no Curso de Gestão da Comunicação e realizado junto ao Instituto Arte na Escola. Nosso objetivo é analisar o papel da comunicação na cultura contemporânea, alicerçado no aporte teórico e conceitual de Jesús Martín-Barbero, que vê a mídia como produtora de cultura e a escola como espaço de re-imaginação e recriação do espaço público. A pesquisa com o público usuário foi fundamentada no conceito de consumo midiático - desenvolvido por Nestor García Canclini - e procura conhecer melhor seus hábitos e preferências. O projeto de intervenção tem a arte como interface, e o site Arte na Escola, como meio de informação e formação para os professores de arte que o acessam. Procura-se, assim, corresponder aos novos paradigmas de um mundo em constante mutação, a fim de possibilitar que os alunos desses professores se tornem sensíveis, críticos, participativos e exigentes.

\section{HISTÓRICO}

O ano era 1989, e Evelyn Berg Ioschpe ${ }^{1}$, então presidente da Fundação Iochpe, estava dedicada a investigar e descobrir caminhos que levassem a educação a apropriar-se dos saberes mediados pela arte. Seu objetivo inicial era melhorar a qualidade do ensino de arte realizado nas escolas de educação formal.

Em 1989, a Fundação Iochpe dava início a uma pesquisa que pretendia comprovar que a Metodologia Triangular, associada à mídia vídeo, era uma eficiente proposta metodológica para o ensino da Arte na Escola. Essa pesquisa culminou em 1992, com a publicação do livro "O Vídeo e a Metodologia Triangular no Ensino da Arte", de Analice Pillar e Denyse Vieira, ambas coordenadoras da pesquisa, elaborada sob orientação da profa. dra. Ana Mae Barbosa.

Tal pesquisa - que deu origem ao Projeto Arte na Escola - desenvolveu-se num período de luta política e conceitual sobre o ensino da arte no Brasil. Um ano antes começava a ser discutida, na Câmara e no Senado, e reestrutu-

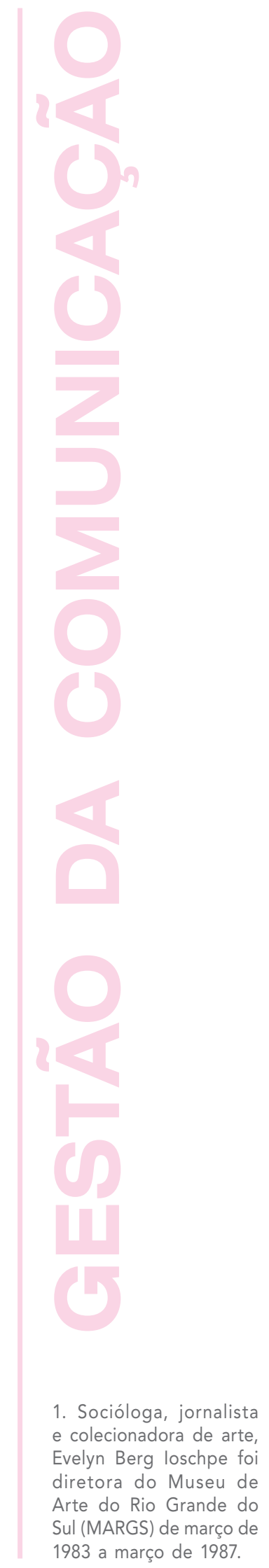


2. Dado obtido por meio da página administrativa do site Arte na Escola, que mostra o total de 20.723 professores cadastrados. Disponível em: $<$ http:// www.artenaescola.org.br/adm/cadastros> Acesso em: 6 ago. 2007. rada, uma nova Lei de Diretrizes e Bases da Educação (LDB), que ameaçava retirar a atividade Artes do currículo escolar de ensino fundamental e médio. O discurso oficial que imperava à época alegava que era preciso recuperar a educação através dos conteúdos, e que arte não tinha conteúdo.

Os resultados da pesquisa, descritos na obra referida, retratam uma reflexão metodológica importante para definir a arte como disciplina escolar, com conteúdos próprios e específicos que respondiam a essa busca, não a limitando apenas a um momento de atividade no currículo escolar, como fora considerada a partir da LDB de 1971, na Lei n. 5.692/71; e também como propunha fazer valer o Conselho Federal de Educação (CFE), a partir de novembro de 1986, ao eliminar a área de Comunicação e Expressão do currículo escolar de ensino fundamental e médio.

Até o surgimento da Metodologia Triangular, com raras exceções, o ensino da arte resumia-se a certo fazer artístico encarado como entretenimento, muitas vezes confundido com artesanato, com a produção de decorações e objetos para festas, principalmente em datas comemorativas. Quem nunca viu crianças saindo das escolas na época da Páscoa com os rostos pintados e as cabeças enfeitadas por orelhas de coelho feitas com cartolina branca e recheadas de algodão?

Foi nesse contexto que Arte na Escola iniciou suas atividades, passando a Fundação Iochpe a se preocupar com a ação de qualificação para o ensino de arte, desenvolvendo atividades junto às universidades brasileiras, por meio de um trabalho extensionista. Hoje, o Arte na Escola, por meio de seu Instituto, conta com 55 pólos universitários distribuídos pelo Brasil, compondo a Rede Arte na Escola, que dissemina e multiplica ações de educação continuada para professores da rede pública de ensino em todo o país, além de distribuir materiais educativos de apoio ao professor.

Apesar das conquistas, as aulas de arte empobrecidas parecem ter atravessado a década de 1990 sem se alterar substancialmente. Elas mantêm-se tradicionais, ainda muito centradas na oralidade e na escrita, em que a imagem e demais recursos audiovisuais são pouco utilizados.

O Instituto Arte na Escola apóia-se também em diversos recursos de comunicação, para atuar junto aos professores de arte e assim fazer valer sua missão, como o site www.artenaescola.org.br, para o qual se volta este trabalho de Gestão da Comunicação.

\section{O SITE ARTE NA ESCOLA}

Hoje o Instituto Arte na Escola abarca uma gama de professores muito além daquela atendida pela Rede Arte na Escola, que, de forma presencial, atinge cerca de 30 mil professores: os usuários do site <http://www.artenaescola.org.br>.

Desde o lançamento de sua segunda versão, no dia $1^{\circ}$ de setembro de 2004, até hoje, a página já atendeu mais de 20 mil professores cadastrados ${ }^{2}$, um número que não pára de crescer. Além disso, seu público usuário vem se 
constituindo e crescendo de forma vertiginosa - o site recebe cerca de 103 mil visitantes únicos por mês. Uma pequena parcela dos professores cadastrados tem acesso às oportunidades de formação continuada oferecidas pela Rede e aos materiais educativos distribuídos, pilares fundamentais para a concretização da missão do Arte na Escola desde seus primórdios. Ou seja, a maior parte do esforço de trabalho empreendido pelo Arte na Escola ocorre de forma presencial, sem um paralelo no ambiente virtual.

O ingresso do Arte na Escola na web teve início em 2001, quando o Instituto elegeu a internet como mídia para ampliar o atendimento aos professores de arte, para além dos pólos da Rede. O objetivo era permitir maior acesso ao material distribuído nos pólos e, sobretudo, propiciar a troca de experiência entre professores, por meio da área Relatos de Experiência. Entretanto, com o site há três anos no ar, os usuários da web pouco acessavam as páginas e nenhum professor havia enviado seus relatos de prática, conforme o esperado.

Como aproximar professores de arte daquilo que de melhor o Arte na Escola pode oferecer utilizando o ambiente virtual, de forma a fazer sentido, estimulando a participação e, com isso, possibilitando que a missão do Instituto encontre nesse meio um outro espaço para se concretizar? Meu encontro com Arte na Escola deu-se justamente no momento em que o Instituto buscava respostas para essa questão complexa, visando à construção de um novo site, o qual tive o privilégio e a oportunidade de empreender.

Acesso e interação foram duas palavras-chave que nortearam meu imaginário durante a concepção da nova página, que surpreendeu, tornando-se ela própria uma promessa de novo ambiente para o Instituto realizar sua ação de incentivar e qualificar o ensino da arte no Brasil.

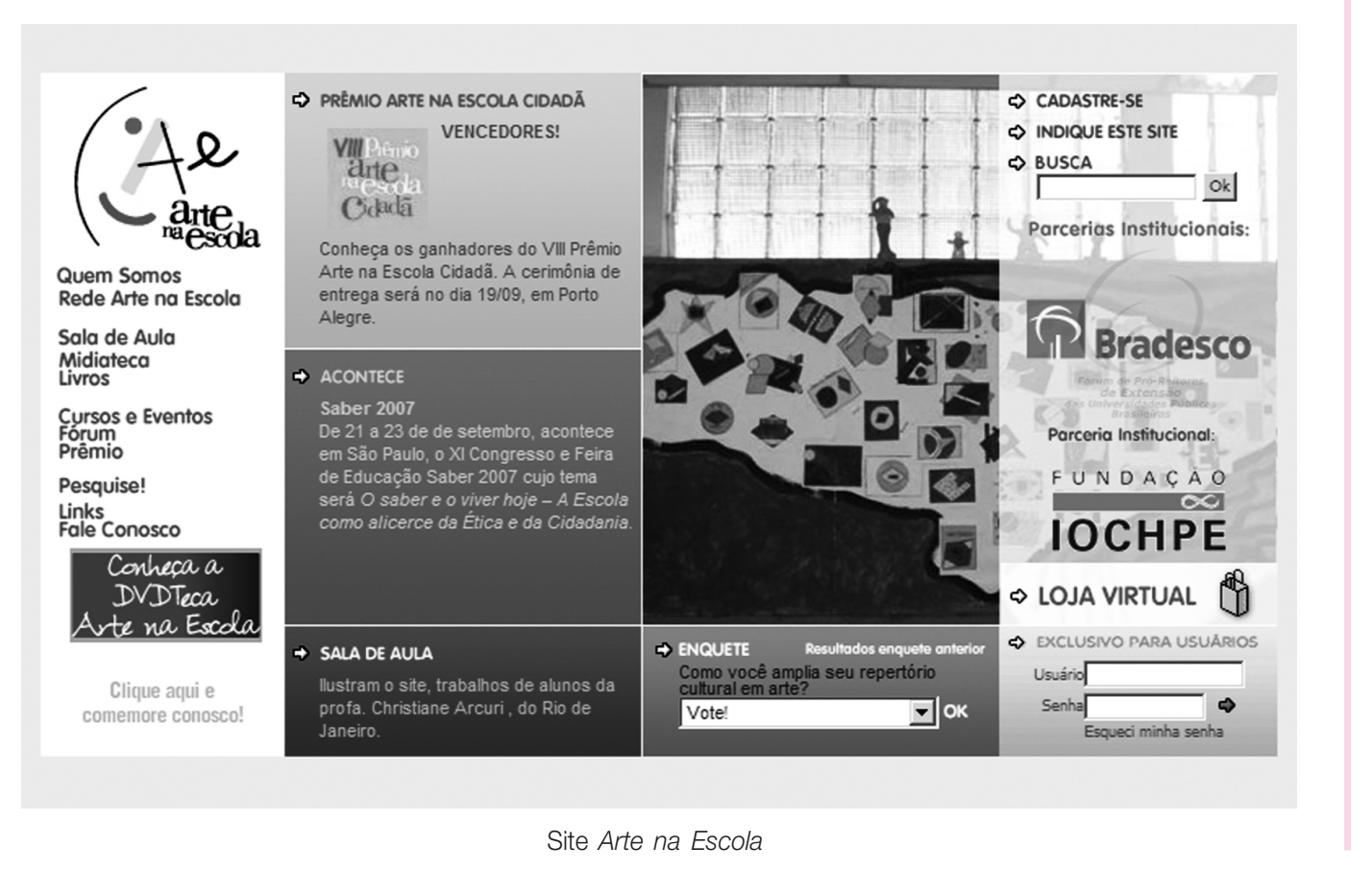




\author{
comunicação \& educação • Ano XII • Número 3 • set/dez 2007
}

\title{
COMUNICAÇÃO DIGITAL: UM NOVO MUNDO DE PERCEPÇÕES E DE PRODUÇÃO DE CONHECIMENTOS
}

Informação e conhecimento estarão cada vez mais relacionados à comunicação digital, e o site Arte na Escola está irremediavelmente inserido nesse contexto.

Conforme Adilson Citelli, o aprendizado acontece agora em campos diversificados e cada vez mais é possível "obter informações e mesmo conhecimentos por meio de mecanismos até há pouco privativos do espaço escolar"'. Fato é que a escola já não é, de modo algum, o único lugar onde se pode aprender conteúdos, e as formas de ver, perceber, apreender, compreender, sentir, processar o mundo mudaram substancialmente.

Segundo o educador e filósofo Mário Sérgio Cortella, estima-se que uma criança de 7 anos de idade já tenha assistido a 5 mil horas de televisão - uma média de 3 horas por dia - quando chega à sala de aula pela primeira vez. Esse dado, por si, sugere que os alunos não são mais os mesmos. Luciano ainda não completou 3 anos de idade e já liga a TV, o DVD e sabe inserir o disco no aparelho para assistir aos seus desenhos prediletos: A Era do Gelo, Bob Esponja, entre outros. Esse menino não faz parte do mundo ficcional; ele é real. É filho de uma amiga e, como ele, existem milhões de outros, todos integrantes da geração que desde muito cedo tem familiaridade com toda sorte de aparatos tecnológicos e com o universo midiático. Ao chegar à escola para ser alfabetizado, Luciano provavelmente já terá visto de tudo um pouco, mediado pela tecnologia e em uma velocidade jamais antes experimentada por nós ou pelas gerações que nos precederam, incluindo, logicamente, os seus professores.

Como formar essas crianças e jovens para a realidade do mundo em que vivem, para o mundo no qual estão imersos e para as grandes transformações que ainda estão por vir? Mais ainda: como muni-los de senso crítico diante da invasão de imagens de toda ordem; de referências significativas; de valores humanos; de vínculos genuínos com o outro e com a realidade concreta? Ainda diante desse cenário, como fazer conviverem a TV, o computador, o DVD, o videogame com o giz, a lousa, o caderno, o livro? E como ficam a arte e o seu ensino nesse cenário, e que papel poderiam desempenhar no contexto da realidade marcada pela explosão de meios de comunicação? Não seria a arte uma potente interface de acesso entre mundo virtual e mundo real?

3. CITELLI, Adilson. Outras linguagens na escola: publicidade, cinema e TV, rádio, jogos, informática. São Paulo: Cortez, 2000. p. 22.

\section{METODOLOGIA DE PESOUISA}

Tendo em vista pesquisar e dar a conhecer as experiências e o background intelectual, cultural e artístico do público cadastrado no site Arte na Escola, foi elaborado um questionário, visando descobrir os hábitos e opiniões dos usuários acerca dos meios de comunicação de massa, segundo o conceito desenvolvido por García Canclini, que caracteriza o consumo não por sua racionalidade econômica, como uma etapa do ciclo produtivo, mas como um processo sociocultural interativo. 


\section{ANÁLISE DESCRITIVA DOS DADOS}

Do total de 2.311 questionários preenchidos, selecionamos 1.253 para constituir a nossa amostra ${ }^{4}$, correspondendo a $10,43 \%$ do total de usuários cadastrados no site. A seguir, apresentamos os principais dados obtidos.

A maior parte dos pesquisados nessa amostra é do sexo feminino (89,15\%), tem em média 37 anos, é casada (51,48\%), natural do Sudeste do Brasil e exerce a profissão de professor $(85,15 \%)$, trabalhando na rede pública de ensino, e, em geral, atua nove anos na mesma escola. Têm boa instrução: 43,97\% cursaram o ensino superior, sendo que $51,16 \%$ deles se formaram em Artes Visuais (Artes Plásticas). Alguns possuem mais de um curso superior e 31,77\% do total chegou à pós-graduação. São consumidores diários de televisão. Para esse público, a televisão é primordialmente um meio de informação, tendo em vista que os programas que afirmam não perder são do gênero jornalístico.

Em uma das questões, foram convocados a dar uma nota de 0 a 10 para variados meios de comunicação, levando em conta o aspecto artístico. É interessante observar que, na opinião deles, apesar de assistirem à televisão diariamente, do ponto de vista artístico essa mídia está para a arte assim como os homens-placa, esses sujeitos que utilizam o corpo como suporte para anúncios publicitários e que ficam perambulando pelas ruas dos centros urbanos. A média geral das notas atribuídas aos meios de comunicação conferiu à "TV" e ao "Homem-Placa" a mesma nota, por sinal a mais baixa: 6. Uma outra tela, a do computador, recebeu nota 8, conferida à Internet. Até mesmo Grafite, uma arte considerada por muitos marginal, obteve nota maior que a TV: 9. Alcançaram nota máxima: Desenho, Pintura, Literatura, Teatro e Música.

Das quatro linguagens da arte, as Artes Visuais são por eles consideradas a "mais artística" de todas. Dentre os movimentos artísticos com os quais os respondentes têm mais facilidade e se sentem mais à vontade para trabalhar com os alunos, os três mais votados, em ordem crescente, foram Cubismo, Impressionismo e Modernismo. Além disso, apontaram mais 383 diferentes nomes de artistas.

Os nossos informantes também foram solicitados a indicar três nomes de artistas com os quais se identificam, e apresentaram 470 diferentes nomes. É interessante observar que os mais citados são artistas ligados a movimentos da História da Arte com os quais esses professores têm mais afinidade, revelada no fato de que se sentem mais à vontade para trabalhar com seus alunos em sala de aula.

Os informantes com computador em casa somam 92,10\%. Costumam acessar a internet todos os dias $(72,62 \%)$, ou pelo menos uma vez por semana. A internet constitui, assim, um meio de informação que oferece uma alternativa de formação continuada para esse público; o tempo disponível gasto na internet por $46,40 \%$ deles, em média, é de uma hora ou mais, e $30,60 \%$ a utilizam por cerca de 30 minutos.
4. O relatório geral da pesquisa está no site: $<$ http://www.artenaescola.org.br/extra_questionario_0310_>. 


\section{ANÁLISE INTERPRETATIVA DOS DADOS}

Os pesquisados estão ávidos por informação e por formação continuada, além de terem uma visão clássica da arte, que, aliás, se deixa entrever em seu repertório midiático e em seus hábitos. Eles já valorizam esse meio. Entretanto, o mesmo não ocorre com os meios de comunicação que consomem e que fazem parte de seu cotidiano, como, por exemplo, a televisão. Sendo na maioria professores, desvalorizam a informação que esses meios de comunicação veiculam diariamente, mas acreditam que, não apenas se poderia municiá-los com temas e conteúdos variados e significativos, mas também deixá-los mais seguros e aptos para trabalharem em convergência com o imaginário que constitui grande parte da realidade de seus alunos, nas escolas da rede pública; imaginário esse formado e consolidado pela TV.

Após nove anos dando aulas, o público usuário do site, identificado com o professor, revela que precisa de reciclagem e o site Arte na Escola apresenta-se como um horizonte de possibilidades.

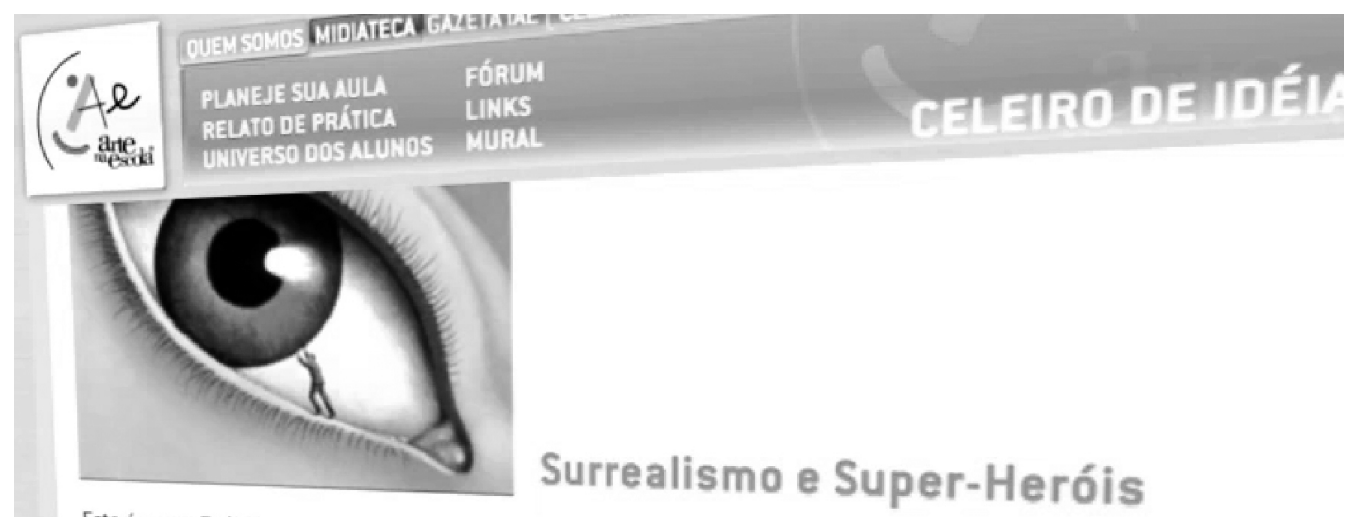

\section{Étée ano Dalio ano en quese} génios do século XX. Embora a sua obra seja identificada com a pintura surrealista, Dalí também
contribuiu para a História do cinema. É a versatilidade do homem que disse que Que ela fosse motion de

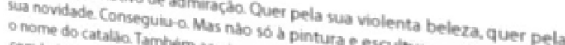

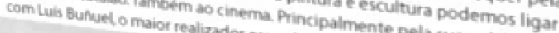

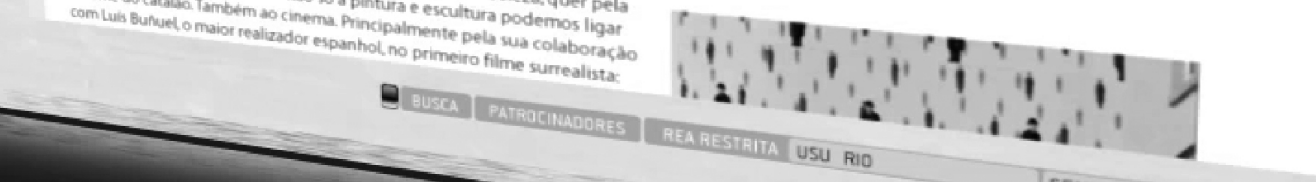

Seção Planeje Sua Aula do protótipo do novo site Arte na Escola: convergência da arte com o repertório dos alunos.

\section{O ENSINO DA ARTE, AS MÍDIAS E ARTE NA ESCOLA ON-LINE}

Habitamos um mundo que vem trocando sua paisagem natural por um cenário criado pelo homem, por onde circulam pessoas, produtos, informações e principalmente imagens. E, se temos que conviver diariamente com essa produção infinita, melhor será aprendermos a avaliar essa paisagem, sua função, sua forma 
e seu conteúdo; e isso requer o uso de nossa sensibilidade estética. Só assim poderemos deixar de ser observadores passivos para nos tornarmos espectadores críticos, participantes e exigentes ${ }^{5}$.

A relação dessa reflexão de Costa com o ensino da arte e seus objetivos é evidente. Ele certamente pode concorrer para aguçar o senso crítico, sensibilizar o olhar para que veja o mundo, ensinando o corpo a vivê-lo e a se expressar nele. Mas o que dizer da aula de Artes que se pratica hoje na escola de ensino formal brasileira e de sua relação com as múltiplas realidades do mundo contemporâneo - mediado por intensos processos comunicacionais, midiáticos e tecnológicos -, nas quais a escola, seus alunos e professores estão imersos? O que a aula de Artes mobiliza e o que significa de fato na experiência dessas instituições, de seus alunos e professores atualmente? Afinal, qual a relação entre a aula de Artes e a vida cotidiana?

Nossa pesquisa indicia que a sala de aula de Artes está estacionada no Modernismo brasileiro. De lá para cá, contudo, o mundo mudou muito. É evidente que esse conhecimento é importante, mas a ausência de referências de arte contemporânea no repertório desses professores chama a atenção. A arte apresentada nas aulas de Artes parece ser aquela que o professor identifica - numa esfera mais da ordem do senso comum que do conhecimento de arte - com obra-prima. É surpreendente que esse professor seja um ávido consumidor das informações veiculadas nos meios de comunicação - bem como o são seus alunos - e que esse conhecimento, essa experiência de atualidade, não seja transferida para o contexto das aulas de Artes. Por quê? A nota atribuída pelos professores à televisão - assim como ao homem-placa - é um indício evidente de um incoerente preconceito contra essa mídia que faz parte atuante de suas vidas.

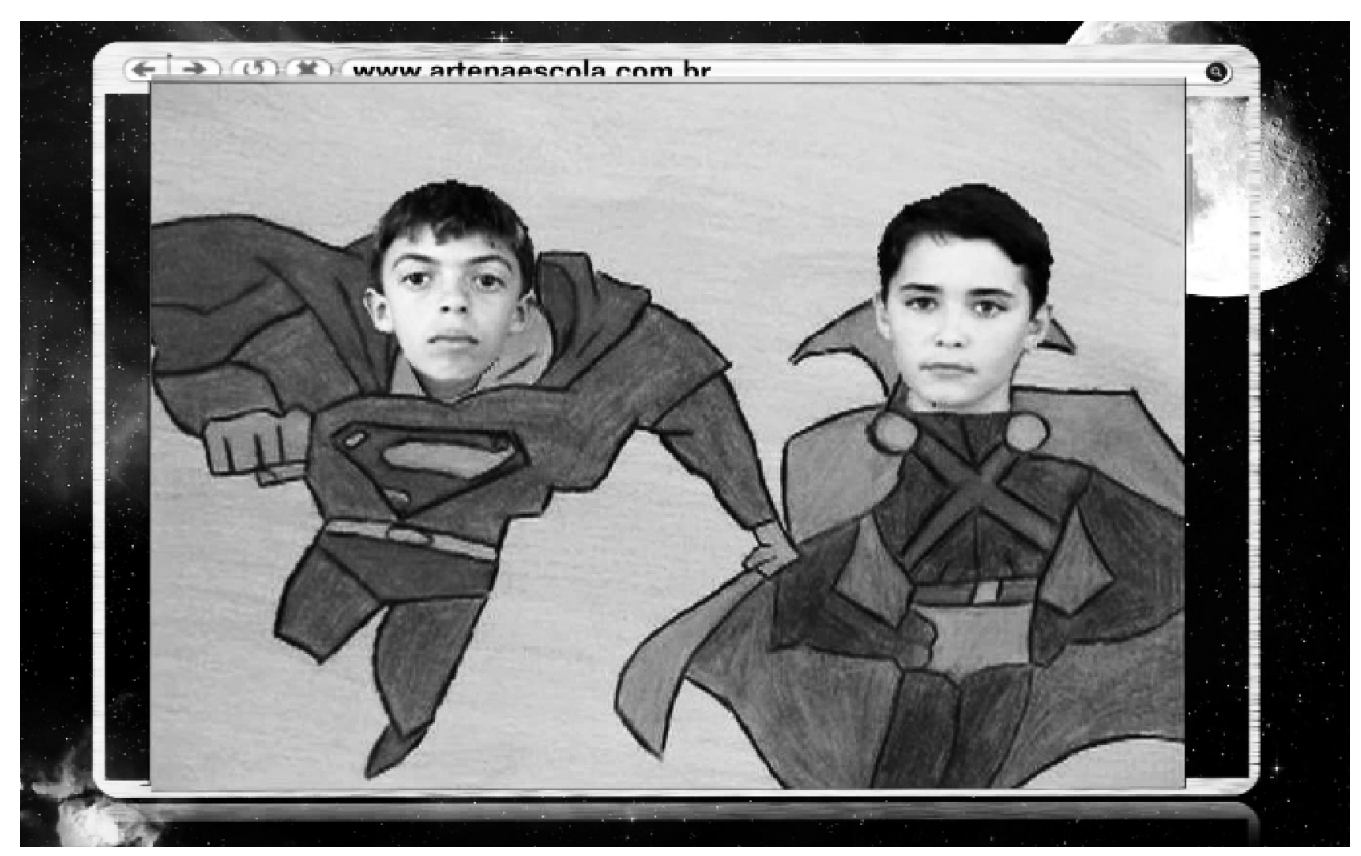

Produção dos alunos da professora Elisabete Bianchi, da Escola Municipal de Ensino Fundamental Abramo Pezzi, de Caxias do Sul-RS.
5. COSTA, Cristina. Questões de arte: o belo, a percepção estética e o fazer artístico. São Paulo: Moderna, 2004. p. 11 e 12. 
Para Martín-Barbero, a escola é o lugar de re-imaginação e recriação do espaço público. E, afinal, a arte é a interface privilegiada para exercer a reimaginação e a re-criação, território de mediação posto entre sujeito, mundo e conhecimento do mundo, permitindo-nos ir além do pensamento convencional e linear do conceito, da descrição e da análise, e levando-nos a visitar espaços desconhecidos dentro e fora de nós, aos quais não teríamos acesso de outra maneira. Devidamente mediada e tratada pela educação escolar como imagem que forma e informa o sujeito para consumir imagens de maneira ativa e crítica, a arte promove o encontro desse sujeito - mestre e aprendiz - consigo mesmo, com o outro e com o mundo.

Ignorar, subestimar, desprezar a informação que circula nos meios de comunicação no contexto da aula de Artes - por medo, desconhecimento, preconceito - é perder a oportunidade de estabelecer um território riquíssimo de diálogo entre a escola e o mundo, o professor e seus alunos, em detrimento de um saber escolarizado elitista, reconhecido e aprovado socialmente, mas que pouco tem favorecido a compreensão e a ressignificação do cotidiano, em prol da formação de cidadãos críticos e sensíveis, comprometidos com as transformações concretas que urgem a sua volta. Não considerar e não incluir parte significativa desse infinito repertório de imagens que nos invade constantemente, possibilitando aos alunos uma interação mais reflexiva e produtiva com e por meio dele, é falar sozinho, desvitalizar a escola e a prática docente e, sobretudo, perpetuar a imutabilidade social.

Martín-Barbero chama a atenção para esse desafio cultural enfrentado hoje pela escola, desafio "que torna visível a distância cada dia maior entre a cultura ensinada pelos professores e aquela aprendida pelos alunos" ${ }^{\circ}$. Ele acredita que a

6. MARTÍN-BARBERO Jesús. Heredando el futuro. Pensar la educación desde la comunicación (Herdando o futuro. Pensar a educação a parti da comunicação). Revista Nómadas, Bogotá: Diuc, 1995. p. 19.

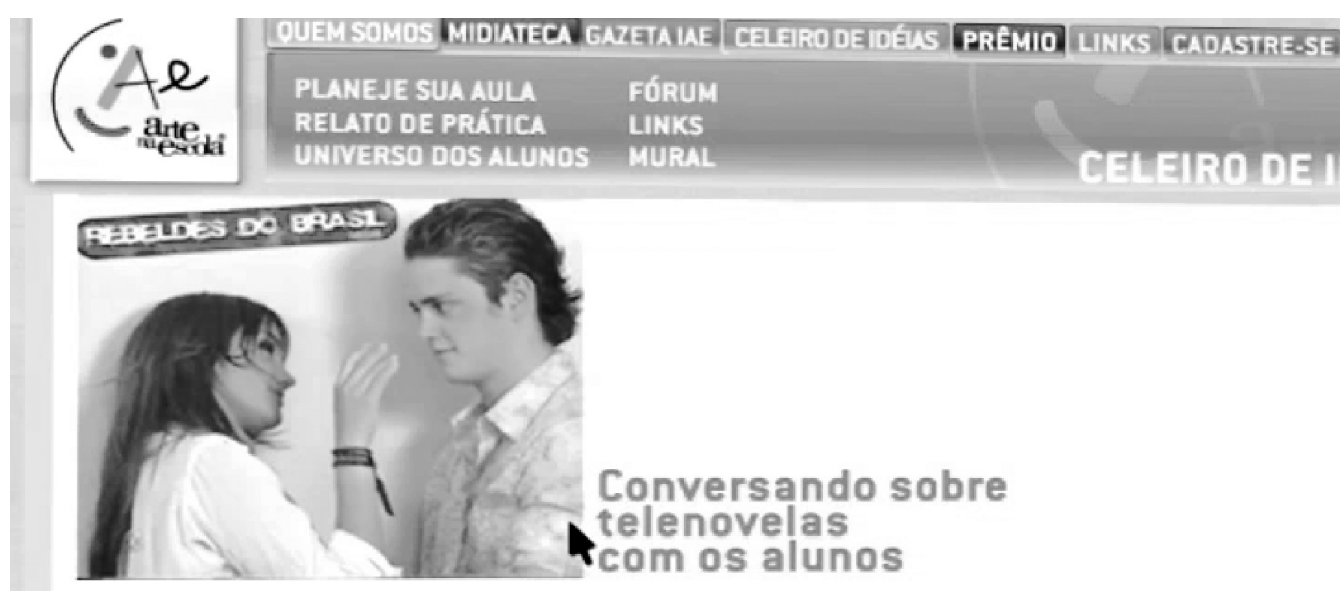

Gênero ou programaçāo importante na agenda da TV brasileira que, em 2006, completo anos de existência no país e faz parte do imaginário de alunos e também de professores No segundo semestre desse ano os grupos de $8^{*}$ e $7^{*}$ série da professora Sandra Costa debateram sobre TELE. NOVELAS. Säo debates calorosos onde colocamos noss opiniáo sobre ética. A novela mais polémica para os grupos até o momento é REBEL DE. Vários questionamentos surgem entre os grupos. Falamos tamberm sobre
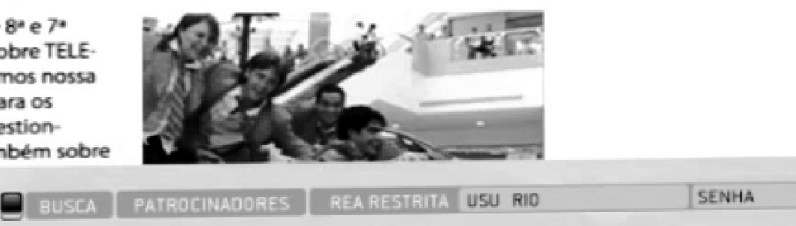

Protótipo do novo site Arte na Escola: sugestão de plano de aula que integra o cotidiano midiático dos alunos. 
mídia é produtora de cultura e que a experiência, portanto, da construção do conhecimento não se dá alheia a ela. É preciso, pois, deixar de negar, na sala de aula de Artes, o universo de imagens e informações que fervilham na TV, na internet, nos games e em outras fontes, imagens e informações continuamente despejadas sobre professores e seus alunos. Todavia, problematizar a televisão, o homem-placa e as imagens que os outdoors veiculam na sala de aula não significa trabalhar qualquer tipo de produção e repertório com os alunos.

É papel do professor ajudar seu aluno a encontrar e construir sentido para as informações que recebe, cada vez menos pela escola, cada vez mais por meio do acesso às mídias digitais, visto que mesmo o aluno da rede pública já tem acesso à internet e a outras fontes midiáticas de informação.

Educar, num contexto complexo, não significa apenas pensar-analisar-interpretar forma e conteúdo, meio e mensagem, mas igualmente sentir-agir-transformar; desse modo, exercendo um papel recriador na realidade cotidiana. Isso implica entender a comunicação midiática como um processo poderoso, além de válido, de construção de conhecimento e de mediação social, nos espaços de produção e transformação da cultura. Por isso, a aula de Artes deveria ser interativa com as mídias e com aquilo que veiculam, em especial as imagens, numa ação recíproca na qual o aluno deixa de ser mero receptor passivo e se transforma num interventor partícipe. Mas como chegar lá? Arte na Escola on-line pode ajudar esse professor usuário a vencer seus preconceitos e fazer com que ele venha a exercer seu papel de protagonista-mediador por meio do ensino da arte, da educação, da sensibilidade que as imagens favorecem e da interação simbólica entre os alunos e o mundo.

\section{ARTE NA ESCOLA ON-LINE INOVADO: UMA PROPOSTA DE INTERVENÇÃO}

Segundo Canclini, o consumo serve para fazer pensar, e é exatamente por isso que este projeto de intervenção quer propor o Arte na Escola, ao instaurar o professor como consumidor midiático e como mediador de mídias, tendo a arte como interface e o site Arte na Escola como meio de sensibilização, informação e formação para os usuários que o acessam. Entendemos ser esse o papel do gestor da comunicação: provocar novos olhares, mais sensíveis, em busca de significados atuais para a realidade, sintonizados com a paisagem do mundo atual, em que a comunicação é um processo, não um aparato meramente instrumental.

A proposta de intervenção compreende a reformulação do site, iniciando com uma nova home, em que a imagem seja privilegiada, dando a ela lugar de destaque, protagonismo e sentido. Inclui também diferenciar as áreas do site, destinadas à divulgação institucional e organizacional; aos serviços (Midiateca); às informações e notícias; e ao relacionamento e à capacitação de professores que o acessam, tornando o site mais auto-explicativo e ainda mais interativo. 


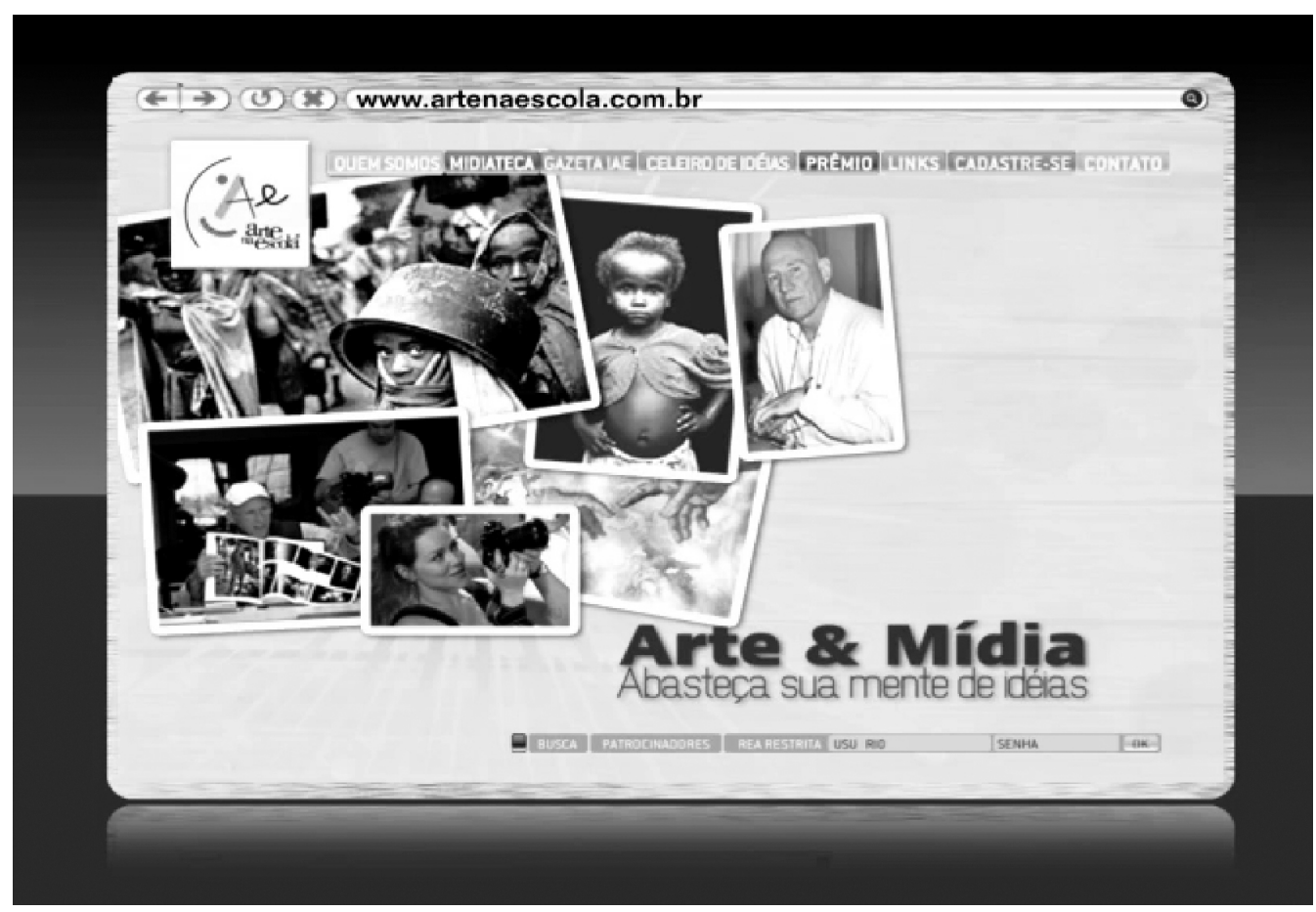

Proposta de home para um novo site do Arte na Escola

Na seção Sala de Aula, inovada, a televisão, o homem-placa e os anúncios veiculados em outdoors poderiam ser problematizados, tendo a arte como interface, além de ser abordados e trabalhados por especialistas em arte e comunicólogos, colaboradores do Instituto, junto aos professores usuários do site.

De acordo com as pesquisas e análises realizadas, o objetivo é ampliar o conceito de arte e divulgar outros paradigmas, bem como sugerir procedimentos e caminhos que auxiliem o professor a incluir em seu repertório - e de seus alunos —, elementos da cultura midiática, melhorando assim o desempenho em sala de aula e possibilitando o desenvolvimento de uma consciência crítica, criativa e sensível, mais comprometida com o cotidiano.

Essa nova estruturação deverá ampliar o grau de interatividade entre os usuários e inovar na apresentação dos conteúdos incluídos pelo Instituto ou postados pelos professores, transformando o site num espaço de aprendizado e de relacionamento com o professor, e estimulando a formação de comunidades virtuais de professores de arte.

Canclini defende que, só através da reconquista criativa dos espaços públicos, o consumo poderá se tornar um espaço para pensar e agir significativamente e de forma renovadora na vida social. O site Arte na Escola on-line, inovado, presente no novo espaço público ilimitado da internet, poderá tornar-se um espaço disponível para essa experiência com o mundo real.

Que os professores de arte de Luciano encontrem Arte na Escola, e isso tanto os auxilie a conferir mais sentido às suas experiências pedagógicas e midiáticas cotidianas, quanto a ser capazes de encaminhar Luciano a esses e a outros sentidos para a vida e para os encontros com o mundo. Que além de 
manusear com maestria as mídias digitais, Luciano possa também aprender a brincar com outras crianças usando botas sujas de barro, num final de tarde depois da chuva no sítio; o que, além de ser muito divertido e inesquecível, é, outrossim, muito educativo e significativo.

Resumo: Este trabalho trata do Projeto Arte na Escola e de seu site. Realizando uma pesquisa com usuários do Arte na Escola on-line, fundamentada no conceito de consumo midiático desenvolvido por Nestor García Canclini, o estudo procurou conhecer as experiências e o background intelectual, cultural e artístico desse público, a fim de propor um projeto de intervenção para atendê-lo. Tal projeto tem a arte como interface e o site Arte na Escola como meio de informação e formação para os professores de arte que o acessam, procurando corresponder aos novos paradigmas de um mundo em constante mutação. A finalidade é possibilitar que os alunos desses professores se tornem sensíveis, críticos, participativos e exigentes.

Palavras-chave: comunicação, arte, educação, mídias, internet, escola, professor, alunos.
Abstract: This study is about the Project Art in School and its website. Through an on line research towards the users of Art in School website, based on the concept of media consumption, developed by Nestor García Canclini, the study aims at knowing this public experiences and their cultural, intellectual and artistic background and it proposes an intervention project in order to assist them. The intervention project has art as its interface, and the Art in School website as a means of information and formation of the art teachers, who access it, looking forward to corresponding to the new paradigms of a world in constant mutation, in order to enable their students to become sensible, critic, participative and demanding.

Keywords: communication, art, education, media, internet, school, teacher, students. 